\title{
EDITORIAL
}

\section{News Coverage by Scholarship}

\author{
SELINE TREVISANUT*
}

\section{INTRODUCTION}

In recent years, newspapers, radios, social networks but also academic journals and blogs have dealt with the many incidents and political debates surrounding the migratory flows in the Mediterranean. Last but not least, the cases of the Aquarius $^{\mathrm{I}}$ and of the Lifeline, ${ }^{2}$ two vessels operated by NGOs which performed search and rescue $(\mathrm{SAR})^{3}$ operations in the Central Mediterranean, have raised many interesting legal issues: the existence of a right to enter into ports; the obligations under international law of the coastal state in whose SAR zone the rescue operation took place, of the state co-ordinating the SAR operation, of the flag state (if any) of the rescuing vessel; etc. These many issues also trigger the application of different fields of international law: the law of the sea ${ }^{4}$ provides the jurisdictional framework; human rights law limits the enforcement powers of the intervening states and provides for some minimum safeguards for the migrants; ${ }^{5}$ refugee law imposes a series of core obligations on the intervening states, such as the principle of non-refoulement; ${ }^{6}$ the rules on the use of force in military operations and in enforcement actions, which

* Member of the Editorial Board, Leiden Journal of International Law; Professor of International Law and Sustainability, Utrecht University [s.trevisanut@uu.nl]. I thank Machiko Kanetake for her invaluable insights and Nina Mileva for her assistance on previous drafts of this contribution. The usual disclaimer applies.

I See, for example, 'Aquarius: What's happening to the migrants on the rescue ship?', BBC Newsround, I 2 June 2018, available at www.bbc.co.uk/newsround/44452893; 'Italy migrants: Who is responsible for helping out at sea?', BBC News, I7 June 2018, available at www.bbc.com/news/world-4445844I; S. Jones, 'Aquarius refusal was betrayal of European values, says charity boss', The Guardian, I 7 June 20I8, available at www.theguardian.com/world/2018/jun/I 7/aquarius-refusal-was-betrayal-of-europeanvalues-says-charity-boss; 'The Aquarius: Migrant taxi service or charitable rescuers?', BBC News, 23 June 20I8, available at www.bbc.com/news/world-europe-4458I764.

2 See, for example, C. Stephen, 'Italy bars two more refugee ships from ports', The Guardian, I 6 June 2018, available at www.theguardian.com/world/2018/jun/I6/italy-bars-two-more-refugee-ships-from-ports; 'Migrant rescue ship Lifeline docks in Malta after days at sea', BBC News, 27 June 2018, available at www.bbc.com/ news/world-europe-44636556.

3 The expression search and rescue is commonly used to describe rescue operations at sea in accordance with the 1979 Convention on Search Rescue, I405 UNTS No. 23489.

4 I 982 United Nations Convention on the Law of the Sea, I833 UNTS No. 31363, and related instruments.

5 See in particular Hirsi Jamaa and others v. Italy, Decision of 23 February 201 2, ECHR 20I 2-II.

6 I95 I Convention Relating to the Status of Refugees, I89 UNTS No. 2545, as amended by the I967 Protocol relating to the Status of Refugees, 606 UNTS No. 879I; in particular Art. 33(I): 'No Contracting State shall expel or return ("refouler") a refugee in any manner whatsoever to the frontiers of territories where his life or freedom would be threatened on account of his race, religion, nationality, membership of a particular social group or political opinion.' 
impose the principles of proportionality and necessity; ${ }^{7}$ etc. Migratory flows in the Mediterranean offer, indeed, much food for thought and discussion for international lawyers who have voiced their concerns and opinions in different formats and fora. Some of those thoughts are, however, not so new. Many of the issues discussed in the last months have been analyzed by scholars over the past 20 years, at the least. ${ }^{8}$ Irregular migration by sea is not a new phenomenon, and contemporary threats to close ports or to refuse disembarkation ${ }^{9}$ certainly have historical precursors. ${ }^{\text {IO }}$

This short editorial discusses the role of scholars in news coverage relating to these current issues. The aim is not to enter into the merits of the issues listed above, nor to assess the arguments put forward in the most recent publications on the issue. The recent episodes of the Aquarius and Lifeline have, indeed, attracted much attention by public opinion and scholars have contributed to academic blogs as well as to newspapers and television programmes. Having myself contributed to these diverse types of interventions, I started wondering to what extent scholars (in their professional capacity) should participate in news coverage and engage in the wider debate through scholarly writings. What are the parameters that journals, such as the Leiden Journal of International Law, should apply in assessing submissions dealing with 'news items' which do not necessarily raise novel legal issues?

I deal with those questions under a double hat: as a scholar who has written articles and blogs and given interviews on the migratory crisis in the Mediterranean; ${ }^{\mathrm{II}}$ and as a member of the editorial board of the Leiden Journal of International Law who has to keep a delicate balance in assessing submissions between the originality of the presented arguments and the participation in on-going debates. Through this double

7 Inter alia, J. Kraska, 'Military Operations', D. Rothwell, et al., (eds.) The Oxford Handbook of the Law of the Sea (20I5), 866, at 873 et seq.; E. Papastavridis, 'The Use of Force at Sea in the 2 Ist Century: Some Reflections on the Proper Legal Framework(s)', (20I5) 2 Journal of Territorial and Maritime Studies I I9.

8 See, for example, in chronological order, B. Oxman, 'Human Rights and the United Nations Convention on the Law of the Sea', (I997) 36 Columbia Journal of Transnational Law 399, at 400; R. Barnes, 'Refugee Law at Sea', (2004) 53 (I) International and Comparative Law Quarterly 47; A. Fischer-Lescano, T. Löhr and T. Tohidipur, 'Border Controls at Sea: Requirements under International Human Rights and Refugee Law', (2009) 2I International Journal of Refugee Law 256; F. Salerno, 'L'obbligo internazionale di non refoulement dei richiedenti asilo', (2010) 4 Diritti umani e diritto internazionale 487; G.S. Goodwin-Gill, 'The Right to Seek Asylum: Interception at Sea and the Principle of Non-Refoulement', (20I I) 23 International Journal of Refugee Law 443; V. Moreno-Lax and E. Papastavridis (eds.) 'Boat Refugees' and Migrants at Sea: A Comprehensive Approach: Integrating Maritime Security with Human Rights (2017).

9 We refer here to the recent positions of the Italian Minister of Interiors, Matteo Salvini, in the abovementioned Aquarius and Lifeline cases, supra notes I and 2.

Io Similar incidents happened during the Indochinese crisis (Opening Statement by the United Nations High Commissioner for Refugees, in Consultative Meeting with Interested Governments on Refugees and Displaced Persons in South East Asia, Geneva, II-I2 December I978, available at www.unhcr.org/uk/admin/ hcspeeches/3ae68fce4c/opening-statement-mr-poul-hartling-united-nations-high-commissioner-refugees. html); the two Haitian crises (see, inter alia, S.H. Legomsky, 'The USA and the Caribbean Interdiction Program', (2006) I8 International Journal of Refugee Law 677); and more recently in the cases of the Tampa (C. Baillet, 'The Tampa Case and its Impact on Burden Sharing at Sea', (2003) 25 Human Rights Quarterly 74I), of the Cap Anamur (S. Trevisanut, 'Le Cap Anamur: profiles de droit international et de droit de la mer', (2004) 9 Annuaire du Droit de la Mer 49), and of the Pinar ('Maroni Claims Malta Sent 40,000 Migrants to Italy', Times of Malta, 2I April 2009, available at www.timesofmalta.com/articles/view/ 2009042 I/local/moroni-claims-malta-sent-40-0oo-migrants-to-italy.253757).

II Inter alia S. Trevisanut, 'The Principle of Non-Refoulement and the De-Territorialization of Border Control at Sea', (2014) 27 (3) Leiden Journal of International Law 66r; S. Trevisanut, 'Aircraft carrier left us to die, say migrants', EJIL:Talk!, 3I May 20II, available at www.ejiltalk.org/“aircraft-carrier-left-us-to-die-saymigrants"/; “Nederlands” reddingsschip zit in juridisch niemandsland', NOS, 22 June 20I8, available at nos.nl/artikel/2237902-nederlands-reddingsschip-zit-in-juridisch-niemandsland.html. 
lens, I discuss two main forms of scholarship: the 'fast scholarship' of academic blogs (Section 2) and the 'engaged slow scholarship' of academic journals (Section 3).

\section{FAST SCHOLARSHIP}

Academic blogs are an insightful source of information and ideas. They offer useful background information and flag the most important elements of recent topics. They are unique opportunities to exchange with scholars from all around the world with certain immediacy thanks to the comment sections; and they are also an interesting writing exercise. Only I 5 years ago, lawyers had mainly four choices concerning the format of their academic writings: comments to a case, in-depth articles/ contributions, monographs, or book reviews/essays. Blog posts are something in between a comment and a newspaper article. Some clear elements of analysis are presented but blog posts, which aim to disseminate information to the wider audience, tend to be superficial, also due to space constraint. They mainly suggest ideas and ways forward for further research. Also, the referencing requirements are different as blog posts do not support traditional footnotes and privilege sources also available online.

Posts about migratory flows in the Mediterranean have appeared in recent years, among others, on three main international law blogs: EJIL:Talk:!';2 Opinio Juris:; ${ }^{13}$ and SIDIblog. ${ }^{\text {I4 }}$ As mentioned above, I have myself contributed to this type of 'fast scholarship' specifically with regard to migratory issues. I remember in particular a frenetic rush to be the first to post on an issue. Because, how many posts can we have on a same issue/event? You want to possibly set the terms of the discussion. For that, you need to be the first mover, and you need to be fast in producing your contribution. Subsequent posts and comments will necessarily interact with the first one, supposing that it meets a minimum level of quality, of course. ${ }^{15}$ This has as a consequence, on the one hand, that sometimes the first posts are merely descriptive, consisting of a good summary of the facts or of recently adopted decisions but offer sparse elements of analysis. On the other hand, some of the subsequent posts may contain sophisticated points of analysis and sharp comments but will go unnoticed because of the multiplication of the sources and the 'old news' effect. ${ }^{16}$

Is this competition against time really productive? Is it really important to be the first one to write about a topic or to be the first blog to deal with an issue?

I2 Blog of the European Journal of International Law (EJIL), available at www.ejiltalk.org.

I3 Independent academic blog, available at opiniojuris.org.

I4 Blog of the Italian Society of International Law (Società Italiana di Diritto Internazionale, SIDI), available at www.sidiblog.org.

I5 See E. Papastavridis, 'The Aquarius Incident and the Law of the Sea: Is Italy in Violation of the Relevant Rules?', EJIL:Talk!, 27 June 2018, available at www.ejiltalk.org/the-aquarius-incident-and-the-law-of-thesea-is-italy-in-violation-of-the-relevant-rules/, in response to M. Fink and K. Gombeer, 'The Aquarius incident: navigating the turbulent waters of international law', EJIL:Talk!, I4 June 2018, available at www. ejiltalk.org/the-aquarius-incident-navigating-the-turbulent-waters-of-international-law/; see also D. Kloza, 'Irregular migration after the Aquarius incident: moving beyond the law. A reflection on Fink and Gombeer', EJIL:Talk!, 5 July 2018, available at www.ejiltalk.org/irregular-migration-after-the-aquariusincident-moving-beyond-the-law-a-reflection-on-fink-and-gombeer/.

I6 After a few weeks and around five posts having already dealt with a specific topic, the sixth post is perceived as 'old news' and will most probably be read by less people, independently of the quality of it. 
Is this competition detrimental to the quality of the analysis and comments? Is this competition transforming academic posts into news coverage? Where to draw the line between scholarship, even if 'fast', and news coverage?

These questions reflect self-inflicted doubts when considering whether to write a post or not. In an era in which almost anyone can improvise being a journalist, many scholars seem to have also given in to this temptation and enjoy the almost immediate visibility blogs provide. There may be nothing wrong with that, in particular when considering that younger scholars now have an important tool to make themselves and their research known, and busy scholars have a platform on which to share their thoughts when they do not have time to write an actual article. In a time in which publications in prestigious journals are required for career advancement or merely for job keeping, it is then also laudable that scholars divert time and energy from this and other main occupations to write posts for a 'wider public'. ${ }^{17}$

To conclude, I am a critical supporter of this fast scholarship. To offer an accurate and succinct picture of what has happened is already a very difficult thing to do in its own right, and is essential to any legal analysis. I then see and experience many of its added value. I also see the potential superficiality of it when it comes to merely reporting facts and events from the news. Visibility and participation in public debate should not be detrimental to academic depth.

\section{ENGAGED SLOW SCHOLARSHIP}

The many legal issues raised by the migratory tragedy in the Mediterranean and mentioned above have also appeared in many international law journals in recent years. Not only specialized ones, such as the International Journal of Refugee Law ${ }^{\mathrm{I}}$ and the International Journal of Marine and Coastal Law, ${ }^{\text {I9 }}$ but also 'generalist' journals, such as the European Journal of International Law, ${ }^{20}$ International and Comparative Law Quarterly, ${ }^{21}$ and our own Leiden Journal of International Law, ${ }^{22}$ have published several articles on related topics.

As already mentioned, many of the issues raised by the migratory flows in the Mediterranean in the last couple of years are not particularly new and the relevant

I7 The wider public of the three main blogs mentioned above remains the international lawyers' community with the addition of some practitioners and students. The composition of the readership emerges from the comments where the different background and expertise are sometimes mentioned.

I8 See, for example, M. Den Heijer, 'Reflections on Refoulement and Collective Expulsion in the Hirsi Case' (2013) 25 (2) International Journal of Refugee Law 265; Goodwin-Gill, supra note 8.

I9 See, for example, I. Papanicolopulu, 'The Law of the Sea Convention: No Place for Persons?', (2012) 27 The International Journal of Marine and Coastal Law 867; E. Papastavridis, 'Enforcement Jurisdiction in the Mediterranean Sea: Illicit Activities and the Rule of Law on the High Seas', (2010) 25 The International Journal of Marine and Coastal Law 569; S. Trevisanut, 'Search and Rescue Operations in the Mediterranean: Factor of Cooperation or Conflict?', (2010) 25 The International Journal of Marine and Coastal Law 523.

20 See, for example, I. Mann, 'Maritime Legal Black Holes: Migration and Rightlessness in International Law', (2018) 29 (2) European Journal of International Law 347.

2I See, for example, D. Ghezelbash, V. Moreno-Lax, N. Klein and B. Opeskin, 'Securitization of Search and Rescue at Sea: The Response to Boat Migration in the Mediterranean and Offshore Australia', (2018) 67 International and Comparative Law Quarterly 315; M. Giuffrè, 'Watered-down Rights on the High Seas: Hirsi Jamaa and Others v Italy', (2012) 6I (3) International and Comparative Law Quarterly 728.

22 See, for example, Trevisanut, supra note I I; S. Kim, 'Non-Refoulement and Extraterritorial Jurisdiction: State Sovereignty and Migration Controls at Sea in the European Context', (2017) 30(I) Leiden Journal of International Law 49. 
international legal framework has unfortunately not particularly changed. ${ }^{23}$ While new actors have entered the field, ${ }^{24}$ and some have changed their positions, ${ }^{25}$ the core legal points remain more or less the same. ${ }^{26}$ What is, then, the role of a journal in participating in ongoing debates triggered by news which certainly have societal relevance but are academically maybe not so interesting? Should those issues only be covered by the 'fast' scholarship of blogs or should the slow scholarship of academic journals also engage? The core and problematic criteria here are the originality and novelty of the submissions to journals.

The Leiden Journal of International Law, for instance, in the editorial policy for submission clearly states that '[i]t aspires to introduce or amplify refreshing and innovative approaches to perennial as well as topical issues ${ }^{27}$ in international law. Is it then refreshing and innovative enough to transpose already expressed arguments to new factual situations? Could it be that to recall already presented ideas and express support for a specific line of reasoning is refreshing enough? Again, I am afraid I do not have clear answers to those queries either. I do, however, believe in the importance of also having an 'engaged scholarship,' namely a scholarship which goes beyond the doctrinal analysis of the relevant legal framework and takes a stand on on-going debates by supporting already presented solutions or approaches; a slow scholarship which does not necessarily present anything innovative but that clearly shows its social engagement.

When human tragedy and deaths are the object of legal reasoning, it is not easy to keep a certain distance and assess arguments only based on their thoroughness and originality, and their contribution to the field of international law. To participate in the debate and highlight already flagged-out elements or show support for more traditional readings of the relevant legal framework consists of an important contribution of academic journals. To point at non-compliance and denounce states' violations consists of an important social function of fast scholarship. To support this with a thorough and solid legal analysis should be the due of slow scholarship. ${ }^{28}$

The structural migratory crisis in the Mediterranean deserves more than just news coverage or the search for sometimes unnecessary novelty. It deserves engagement. And law journals should host and nourish such engagements.

23 We focus here on the international legal framework and not on the developments at the EU and/or domestic levels.

24 See, for example, E. Cusmano, 'The sea as humanitarian space: Non-governmental Search and Rescue dilemmas on the Central Mediterranean migratory route', (2018) 23 (3) Mediterranean Politics 387, discussing the role of NGOs in the Mediterranean refugee crisis.

25 Italy policy has changed after the outcome of the political elections in March 20I8. The new coalition in place includes the extreme right and xenophobic party, la Lega. The leader of la Lega, Matteo Salvini, is currently the Italian Minister of the Interior.

26 Those points are mainly three: the content of the obligation to render assistance; to define the bearer(s) and the recipient(s) of this obligation; the treatment to be granted to the rescued migrants, in particular when they are refugees among them.

27 Emphasis added; the editorial policy of the Leiden Journal is available at www.cambridge.org/core/journals/ leiden-journal-of-international-law/information/instructions-contributors

28 On the benefits of self-questioning by scholars and the delicate balance between participating in currents debates and remaining non-interested (critical) observers see M. Craven, G. Simpson, S. Marks and R. Wilde, 'We Are Teachers of International Law', (2004) I 7 Leiden Journal of International Law 363; I. Feichtner, 'Critical Scholarship and Responsible Practice of International Law. How Can the Two be Reconciled?', (20I6) 29 Leiden Journal of International Law 979, at 99I-2. 